University of Nebraska - Lincoln

DigitalCommons@University of Nebraska - Lincoln

Stocking Strategies for Production of Litopenaeus vannamei (Boone) in Amended Freshwater in Inland Ponds

\author{
Bartholomew W. Green \\ USDA, Agricultural Research Service, bart.green@usda.gov
}

Follow this and additional works at: https://digitalcommons.unl.edu/usdaarsfacpub

Part of the Agriculture Commons, and the Aquaculture and Fisheries Commons

Green, Bartholomew W., "Stocking Strategies for Production of Litopenaeus vannamei (Boone) in Amended Freshwater in Inland Ponds" (2008). Publications from USDA-ARS / UNL Faculty. 2479. https://digitalcommons.unl.edu/usdaarsfacpub/2479

This Article is brought to you for free and open access by the U.S. Department of Agriculture: Agricultural Research Service, Lincoln, Nebraska at DigitalCommons@University of Nebraska - Lincoln. It has been accepted for inclusion in Publications from USDA-ARS / UNL Faculty by an authorized administrator of DigitalCommons@University of Nebraska - Lincoln. 


\title{
Stocking strategies for production of Litopenaeus vannamei (Boone) in amended freshwater in inland ponds
}

\author{
Bartholomew W Green \\ USDA-ARS Aquaculture Systems Research Unit, Aquaculture/Fisheries Center of Excellence, University of Arkansas at Pine \\ Bluff, Pine Bluff, AR, USA
}

Correspondence: B W Green, USDA-ARS Aquaculture Systems Research Unit, Aquaculture/Fisheries Center of Excellence, University of Arkansas at Pine Bluff, 1200 North University Drive, MS 4912, Pine Bluff, AR 71601, USA. E-mail: bart.green@ars.usda.gov

\begin{abstract}
The performance of the Pacific white shrimp Litopenaeus vannamei (Boone) under various stocking strategies was evaluated in earthen ponds filled with freshwater amended with major ions. Six 0.1-ha earthen ponds located in Pine Bluff, AR, USA, were filled with freshwater in 2003 and 2004, and potassium magnesium sulphate added to provide $50 \mathrm{mg} \mathrm{K}^{+} \mathrm{L}^{-1}$ and stock salt added to provide $0.5 \mathrm{~g} \mathrm{~L}^{-1}$ salinity. In 2003, three ponds either were stocked with $\mathrm{PL}_{15}$ shrimp (39 $\mathrm{PL} \mathrm{m}^{-2}$ ) for 125 days of grow out or with $\mathrm{PL}_{25}$ shrimp for 55 days $\left(23 \mathrm{PL} \mathrm{m}^{-2}\right)$ followed by a 65 -day $\left(28 \mathrm{PL} \mathrm{m}^{-2}\right)$ growout period. In 2004, ponds were stocked with 7,13 or $30 \mathrm{PL}_{15} \mathrm{~m}^{-2}$ for 134 days of grow out. Salinity averaged $0.7 \mathrm{~g} \mathrm{~L}^{-1}$ during both years, and concentration of $\mathrm{SO}_{4}^{-2}, \mathrm{~K}^{+}, \mathrm{Ca}^{2+}$ and $\mathrm{Mg}^{2+}$ was higher, and $\mathrm{Na}^{+}$ and $\mathrm{Cl}^{-}$was lower in amended pond water than in seawater at $0.7 \mathrm{~g} \mathrm{~L}^{-1}$ salinity. Potassium concentration in amended water was $52-61 \%$ of the target concentration. Shrimp yields ranged from $3449 \mathrm{~kg} \mathrm{ha}^{-1}$ in 2003 to $4966 \mathrm{~kg} \mathrm{ha}^{-1}$ in 2004 in ponds stocked with 30-39 $\mathrm{PL}_{15} \mathrm{~m}^{-2}$ for a 125-134-day culture period. At harvest, mean individual weight ranged from 17.1 to $19.3 \mathrm{~g}$ shrimp ${ }^{-1}$. In ponds stocked with $\mathrm{PL}_{25}$ shrimp, yields averaged 988 and $2462 \mathrm{~kg} \mathrm{ha}^{-1}$ for the 1st and 2nd grow-out periods respectively. Gross shrimp yield in 2004 increased linearly from $1379-4966 \mathrm{~kg} \mathrm{ha}^{-1}$ with increased stocking rate. These experiments demonstrated that L. vannamei can be grown successfully in freshwater supplemented with major ions to a final salinity of $0.7 \mathrm{~g} \mathrm{~L}^{-1}$.
\end{abstract}

Keywords: Litopenaeus vannamei (Boone), freshwater, mineral amendment, aquaculture, inland ponds

\section{Introduction}

The Pacific white shrimp Litopenaeus vannamei (Boone) is being cultured far from coastal areas in ponds filled with low-salinity (generally $2-5 \mathrm{~g} \mathrm{~L}^{-1}$ ) ground water or brine transported from the coast and diluted on site with freshwater. Six ions in seawater comprise $99.8 \%$, by weight, of salinity: $\mathrm{Cl}^{-}$ (55.3\%), $\mathrm{Na}^{+}$(30.8\%), $\mathrm{SO}_{4}^{2-}(7.7 \%), \mathrm{Mg}^{2+}$ (3.7\%), $\mathrm{Ca}^{2+}(1.2 \%)$, and $\mathrm{K}^{+}(1.1 \%)$. The ionic composition of low-salinity ground water varies geographically and often differs from that of dilute seawater at the same salinity. Boyd and Thunjai (2003) and Saoud, Davis and Rouse (2003) collected water samples for ion analysis from inland shrimp ponds and wells in Alabama, Arizona, Florida, Mississippi and Texas in the United States and in Australia, China, Ecuador and Thailand. Although ion concentrations in many samples were similar to those of dilute seawater at the same salinity, there were some notable deviations. Deficiencies in chloride, magnesium, potassium and sulphate were observed in some samples, while excesses of calcium and sulphate were observed in other samples. Relative to dilute seawater at the same salinity, ion deficiencies were most common in ponds filled with low-salinity ground water.

The availability of brackish ground water in noncoastal regions provides an opportunity to culture 
marine species able to adapt to reduced salinity. Ratios of major ions in low-salinity ground water may serve as indicators of the suitability of brackish ground water for aquaculture. Among the ionic ratios that have been evaluated in relation to survival and growth of marine species are $\mathrm{Na}^{+}: \mathrm{K}^{+}$and $\mathrm{K}^{+}: \mathrm{Cl}^{-}$for red drum (Sciaenops ocellatus [Linneaus]) (Forsberg, Dorsett \& Neill 1996), $\mathrm{K}^{+}: \mathrm{Cl}^{-}$for Australian snapper (Pagrus auratus [Forster]) (Fielder, Bardsley \& Allan 2001), $\mathrm{Na}^{+}: \mathrm{Ca}^{2+}$ (Atwood, Young, Tomasso \& Browdy 2003) and $\mathrm{Na}^{+}: \mathrm{K}^{+}$(Zhu, Dong, Wang \& Huang 2004) for L. vannamei. These ratios also can be used to develop remediation strategies to correct ionic imbalances.

Ionic imbalance in inland saline ground water can affect shrimp survival. Saoud et al. (2003) reported variable $L$. vannamei survival $48 \mathrm{~h}$ after initiating acclimation to $0.7-16.3 \mathrm{~g} \mathrm{~L}^{-1}$ salinity well waters from various sources. Farmers in the southern United States have reported poor growth and survival for L. vannamei stocked in inland ponds filled with lowsalinity water deficient in one or more ions. Addition of specific fertilizers to supply or augment concentrations of specific deficient ions appeared to solve the problem. Boyd and Thunjai (2003) and McNevin, Boyd, Silapajarn and Silapajarn (2004) recommended a number of minerals that could be used to supplement major cations in low-salinity water.

Because low-salinity ground water can be amended to supply one or more deficient ions, it should be possible to amend water from freshwater ( $<0.5 \mathrm{~g} \mathrm{~L}^{-1}$ salinity) aquifers to support successful shrimp culture. Results of a preliminary trial conducted in 2002 showed that L. vannamei survived and grew in freshwater supplemented with major ions (B. W. Green, unpublished data). In that trial, a target of $50 \mathrm{mg} \mathrm{K}^{+} \mathrm{L}^{-1}$ was selected to ensure adequate soluble $\mathrm{K}^{+}$in pond water because $\mathrm{K}^{+}$can be adsorbed strongly by clay soils (Bohn, McNeal \& O'Connor 1985). Furthermore, similar levels of $\mathrm{K}^{+}$supplementation were practiced in Alabama in response to shrimp mortality putatively caused by $\mathrm{K}^{+}$deficiency (McNevin et al. 2004). Potassium magnesium sulphate fertilizer, selected because it provides three major ions, was applied to provide $50 \mathrm{mg} \mathrm{K}^{+} \mathrm{L}^{-1}$.

In inland culture in the United States, shrimp 17.521.0 g shrimp $^{-1}$ and larger are considered marketable (Samocha, Hamper, Emberson, Davis, McIntosh, Lawrence \& Van Wyk 2002). Thus, the objective of the present research was to evaluate the performance of L. vannamei under different stocking strategies for producing marketable shrimp in earthen ponds filled with freshwater amended with major ions.

\section{Materials and methods}

Trials were conducted in 2003 and 2004. In both trials, six 0.1-ha earthen ponds located on the Aquaculture Research Station, University of Arkansas at Pine Bluff, Pine Bluff, AR, were filled with freshwater (total alkalinity $126 \mathrm{mg} \mathrm{L}^{-1}$ as $\mathrm{CaCO}_{3}$; total hardness $162 \mathrm{mg} \mathrm{L}^{-1}$ as $\mathrm{CaCO}_{3}$ ) from a 2.0-ha reservoir. Water to fill the reservoir was pumped from a 61-m-deep well. Pond water levels were maintained approximately $15 \mathrm{~cm}$ below the top of the standpipe to capture rainfall. Reservoir water was added as needed to maintain water level in ponds $15-30 \mathrm{~cm}$ below the top of the standpipe. No water was exchanged in ponds. Each pond was equipped with a 0.37-kW electric paddlewheel aerator (Southern Machine Welding, Quinton, AL, USA) that was operated nightly during each trial.

Before flooding agricultural limestone (250 mesh) was spread on pond bottoms (Table 1). Livestock salt (ca. 96\% $\mathrm{NaCl}$ ) and potassium magnesium sulphate fertilizer (K-MAG Standard guaranteed analysis: $22.0 \% \mathrm{~K}_{2} \mathrm{O}, 10.8 \% \mathrm{Mg}, 22.0 \% \mathrm{~S}$, The Mosaic Company, Plymouth, MN, USA) (Table 1) was added to ponds generally to increase concentrations of the six major ions found in seawater and specifically to increase $\mathrm{K}^{+}$concentration. Target concentrations selected were $50 \mathrm{mg} \mathrm{K}^{+} \mathrm{L}^{-1}$ from potassium magnesium sulphate and $0.5 \mathrm{~g} \mathrm{~L}^{-1}$ of salinity from the livestock salt. Input quantities were reduced in 2004 based on 2003 water analysis results and improved pond volume estimates. The potassium magnesium sulphate was dissolved in pond water in buckets before being applied to the pond. During the first 21 days of both years, two of the six ponds lost water to seepage and received an additional $1130-1361 \mathrm{~kg} \mathrm{ha}^{-1}$ of livestock salt to replace salinity lost to dilution.

Table 1 Quantities of agricultural limestone (250 mesh), livestock salt (ca. 96\% $\mathrm{NaCl}$ ), and potassium magnesium sulphate $(0-0-2211 \% \mathrm{Mg} 22 \% \mathrm{~S})$ added to inland freshwater ponds to increase mean salinity to $0.7 \mathrm{~g} \mathrm{~L}^{-1}$

\begin{tabular}{|c|c|c|c|}
\hline Trial year & $\begin{array}{l}\text { Agricultural } \\
\text { limestone } \\
\left(\mathbf{k g ~ h a}^{-1}\right)\end{array}$ & $\begin{array}{l}\text { Livestock } \\
\text { salt }\left(\mathbf{k g ~ h a}^{-1}\right)\end{array}$ & $\begin{array}{l}\text { Potassium } \\
\text { magnesium } \\
\text { sulphate fertilizer } \\
\left(\mathbf{k g ~ h a}^{-1}\right)\end{array}$ \\
\hline 2003 & 1100 & 5670 & 3175 \\
\hline 2004 & 567 & 4536 & 2722 \\
\hline
\end{tabular}


Water samples were collected in 2003 from each of three randomly selected ponds before and from all ponds 1 day after salinity adjustment and from three ponds after 125 days of continuous culture. The Water Quality Laboratory, Arkansas Water Resources Center, University of Arkansas, Fayetteville, AR, USA, analysed all water samples for fluoride, chloride and sulphate using ion chromatography (IC), and calcium, magnesium, potassium and sodium using inductively coupled plasma spectroscopy (ICP). In addition, two of the day-125 samples were analysed for aluminum, cobalt, copper, iron, manganese, molybdenum and zinc by ICP. In 2004, two samples of pipe water discharging into ponds during pond flooding were collected for ion analysis. Water samples were collected from all ponds on days 5, 105, and 134. All 2004 water samples were analysed on-site using IC for calcium, chloride, magnesium, potassium, sodium and sulphate.

In 2003, each pond was fertilized with cottonseed meal and chemical fertilizer (19-19-19) on days 1 and 6 after filling to stimulate natural productivity. A total of $225 \mathrm{~kg} \mathrm{ha}^{-1}$ cottonseed meal and $30 \mathrm{~kg} \mathrm{ha}^{-1}$ 19-19-19 were added. In 2004, each pond was fertilized to stimulate natural productivity 1 day after filling with cottonseed meal $\left(227 \mathrm{~kg} \mathrm{ha}^{-1}\right)$, wheat bran $\left(227 \mathrm{~kg} \mathrm{ha}^{-1}\right.$ ) and minnow meal $\left(73 \mathrm{~kg} \mathrm{ha}^{-1}\right)$. Each pond was fertilized (38.6 $\left.\mathrm{kg} \mathrm{ha}^{-1}, 19-19-19\right)$ on days 1,7 and 14. Chemical fertilizer was dissolved in pond water in a bucket before being applied to the pond.

Postlarval ( $\mathrm{PL}_{15}$ and $\mathrm{PL}_{25}$ ) L. vannamei (BP101 line), purchased both years from the GMSB Shrimp Hatchery in Florida, USA, were held in tanks for $56 \mathrm{~h}$ while acclimated to pond salinity. Shrimp were fed during acclimation with a $50 \%$ protein feed $(850-1200 \mu \mathrm{m}$ particle size; PL Raceway Plus, Zeigler Brothers). At stocking, average individual PL weight was determined by dividing the bulk weight of PLs in a tared beaker of water by the number of PLs. Numbers at stocking were determined gravimetrically.

A completely randomized design was used for both trials. Producing one or two crops in a single growing season was tested in 2003. The planned stocking rate (33 PL m ${ }^{-2}$ ) was similar to that used at inland farms; however, PL availability following acclimation resulted in deviation from the plan. Three ponds were stocked on 30 May 2003 with $39 \mathrm{PL}_{15}$ shrimp m ${ }^{-2}$ and grown for the entire growing season (125 days). The other three ponds were stocked the same day with $23 \mathrm{PL}_{25}$ shrimp m ${ }^{-2}$, grown for 55 days, and harvested. Ponds were re-flooded, salinity adjusted to $0.7-0.8 \mathrm{~g} \mathrm{~L}^{-1}$, and $28 \mathrm{PL}_{25}$ shrimp m${ }^{-2}$ were stocked on 1 August 2003 and grown for 65 days. The effect on growth and yield of stocking 7, 13 or $30 \mathrm{PL}_{15} \mathrm{~m}^{-2}$ was tested in 2004. On 8 May 2004 ponds in the 7 and $13 \mathrm{PL}_{15} \mathrm{~m}^{-2}$ treatments were stocked completely. Ponds in the $30 \mathrm{PL}_{15} \mathrm{~m}^{-2}$ treatment were stocked partially (60\%) because of insufficient PLs; stocking was completed on 15 May 2004 upon receipt of a second PL shipment. Ponds were harvested on 20-21 September 2004.

Shrimp in all ponds were fed a commercially formulated, sinking, extruded shrimp diet $35 \%$ crude protein, Shrimp Grow-Out SI-35, Zeigler Brothers), 7 days week $^{-1}$. A constant quantity of feed (22.7 and $13.6 \mathrm{~kg} \mathrm{ha}^{-1}$ in 2003 and 2004 respectively) was added to ponds daily for the first 27-33 days. Beginning days 28-34, feeding rate was adjusted weekly, decreasing from $8.2 \%$ to $1.8 \%$ of the biomass as shrimp grew (Clifford III 1992). The shrimp population in each pond was sampled weekly beginning days 28-34 to monitor growth. Shrimp (20-25 shrimp pond ${ }^{-1}$ ) were captured using a cast net, weighed individually to the nearest $0.1 \mathrm{~g}$, and returned to the pond. Specific growth rate (SGR) of shrimp was calculated: $\mathrm{SGR}=100 \times\left(\ln W_{t+1}-\ln \right.$ $\left.W_{t}\right) /\left(T_{t+1}-T_{t}\right)$, where $\ln W=$ natural logarithm of mean individual weight $\left(\mathrm{g} \mathrm{shrimp}^{-1}\right)$ at time $t+1$ or $t$, and $T=$ time (d) $t+1$ or $t$. Shrimp were harvested by draining the pond. The total weight of shrimp harvested per pond was measured. A sample of 100 shrimp pond ${ }^{-1}$ was weighed individually to the nearest $0.1 \mathrm{~g}$. Total number of shrimp harvested per pond was calculated by dividing the total biomass harvested by the mean individual weight. Gross feed conversion ratio was calculated for each replicate by dividing the total weight of feed offered by the total weight of shrimp harvested.

Dissolved oxygen concentration and water temperature were measured daily in ponds between 07:00-08:00 hours, and periodically between 14:00 and 15:00 hours using a YSI oxygen meter (Model 550A, Yellow Springs Instrument, Yellow Springs, OH, USA). Salinity was measured in ponds every 12 days on an average in 2003 and daily in 2004 using a YSI salinity meter (Model 30, Yellow Springs Instrument).

Production data for 2003 were analysed using PROC GLM and regression analysis; percent data were arcsin transformed before analysis (Sokal \& Rohlf 1995). Water analyses data for 2003 and 2004 were analysed using a statistical model for repeated measures in the mixed models procedure (PROC MIXED). Data analyses were performed using SAS 
Version 9.1 software (SAS Institute, Cary, NC, USA). Net feed conversion ratio was calculated by dividing the total quantity of feed fed by the net yield. Differences were declared significant at $\alpha$ level 0.05 .

\section{Results}

Salinity of pond water before ionic amendment was $0.15-0.20 \mathrm{~g} \mathrm{~L}^{-1}$. Mineral addition increased mean concentration of major cations and anions (Table 2). Mean pond salinity in both years increased to $0.7-0.9 \mathrm{~g} \mathrm{~L}^{-1}$ immediately following ionic amendment and averaged $0.7 \mathrm{~g} \mathrm{~L}^{-1}$ for each grow out cycle. Compared with seawater at $0.7 \mathrm{~g} \mathrm{~L}^{-1}$ salinity, mean ion concentrations in amended water were higher for calcium, magnesium and potassium, and lower for chloride and sodium.

The effect of ion amendment of major ions persisted throughout the culture period during both years (Table 2). Maximum mean ion concentrations were observed in water samples collected on day 1 (2003) and day 5 (2004). During both years, mean concentration of calcium, magnesium and potassium at the end of the culture period exceeded their corresponding concentration in seawater at $0.7 \mathrm{~g} \mathrm{~L}^{-1}$ salinity. Mean sodium and chloride concentration at the end of the culture period during both years was less than their corresponding concentration in seawater at $0.7 \mathrm{~g} \mathrm{~L}^{-1}$ salinity.

Potassium concentration in amended water failed to attain the target of $50 \mathrm{mg} \mathrm{K}^{+} \mathrm{L}^{-1}$ in either year (Table 2).

The $\mathrm{Na}^{+}: \mathrm{K}^{+}$and $\mathrm{Ca}^{+2}: \mathrm{Mg}^{+2}$ ratios of pond water decreased following addition of salts and then increased slightly during both years (Table 2). The $\mathrm{Na}^{+}: \mathrm{Ca}^{+2}$ ratio increased slightly following fertilization, then decreased. The $\mathrm{K}^{+}: \mathrm{Cl}^{-}$ratio increased following fertilization and throughout the 125-day culture period in 2003, whereas the ratio decreased throughout the culture period in 2004. In comparison, the $\mathrm{Na}^{+}: \mathrm{K}^{+}, \mathrm{Na}^{+}: \mathrm{Ca}^{+2}, \mathrm{~K}^{+}: \mathrm{Cl}^{-}$and $\mathrm{Ca}^{+2}: \mathrm{Mg}^{+2}$ ratios in $0.7-\mathrm{g} \mathrm{L}^{-1}$ seawater were higher, higher, lower and lower, respectively, than in the amended pond water.

Table 2 Mean concentration of ions $\left(\mathrm{mg} \mathrm{L}^{-1}\right)$ in 2003 and 2004 in source water and in pond water at various times after mineral amendment. Salinity in ponds during both years averaged $0.7 \mathrm{~g} \mathrm{~L}^{-1}$ following amendment*

\begin{tabular}{|c|c|c|c|c|c|c|c|c|}
\hline \multirow[b]{2}{*}{ Ion } & \multicolumn{3}{|l|}{2003} & \multicolumn{4}{|l|}{2004} & \multirow{2}{*}{$\begin{array}{l}0.7 \mathrm{~g} \mathrm{~L}^{-1} \\
\text { seawater }\end{array}$} \\
\hline & Source water & Day 1 & Day 125 & Source water & Day 5 & Day 105 & Day 134 & \\
\hline $\mathrm{Cl}^{-}$ & $33.8^{\mathrm{c}}$ & $239.0^{\mathrm{a}}$ & $183.2^{\mathrm{b}}$ & $26.8^{d}$ & $349.6^{a}$ & $253.8^{\mathrm{b}}$ & $207.5^{c}$ & 393.7 \\
\hline $\mathrm{SO}_{4}^{-2}$ & $36.5^{\mathrm{b}}$ & $136.1^{\mathrm{a}}$ & $71.7^{\mathrm{ab}}$ & $12.1^{\mathrm{b}}$ & $54.2^{\mathrm{a}}$ & $21.3^{\mathrm{b}}$ & $23.0^{\mathrm{b}}$ & 55.2 \\
\hline $\mathrm{Na}^{+}$ & $56.6^{\mathrm{b}}$ & $161.4^{\mathrm{a}}$ & $197.1^{\mathrm{a}}$ & $45.9^{c}$ & $242.5^{\mathrm{a}}$ & $188.9^{b}$ & $170.4^{\mathrm{b}}$ & 219.1 \\
\hline $\mathrm{K}^{+}$ & $3.8^{\mathrm{b}}$ & $28.1^{\mathrm{a}}$ & $28.6^{\mathrm{a}}$ & $2.6^{c}$ & $32.1^{\mathrm{a}}$ & $18.9^{b}$ & $15.6^{\mathrm{b}}$ & 8.1 \\
\hline $\mathrm{Ca}^{+2}$ & $27.1^{a}$ & $38.9^{\mathrm{a}}$ & $54.9^{\mathrm{a}}$ & $21.3^{\mathrm{b}}$ & $43.5^{\mathrm{a}}$ & $37.0^{\mathrm{a}}$ & $37.2^{\mathrm{a}}$ & 8.4 \\
\hline $\mathrm{Mg}^{+2}$ & $17.7^{\mathrm{b}}$ & $33.2^{\mathrm{ab}}$ & $45.6^{a}$ & $19.1^{c}$ & $40.0^{\mathrm{a}}$ & $29.1^{\mathrm{b}}$ & $26.8^{\mathrm{b}}$ & 26.2 \\
\hline $\mathrm{Na}^{+}: \mathrm{K}^{+}$ & 25.1 & 9.8 & 11.7 & 26.9 & 12.8 & 17.0 & 18.6 & 45.9 \\
\hline $\mathrm{Na}^{+}: \mathrm{Ca}^{+2}$ & 3.6 & 7.2 & 6.3 & 3.7 & 9.7 & 8.9 & 8.0 & 45.6 \\
\hline $\mathrm{K}^{+}: \mathrm{Cl}^{-}$ & 0.102 & 0.107 & 0.142 & 0.089 & 0.083 & 0.067 & 0.068 & 0.019 \\
\hline $\mathrm{Ca}^{+2}: \mathrm{Mg}^{+2}$ & 0.93 & 0.71 & 0.73 & 0.68 & 0.66 & 0.77 & 0.84 & 0.19 \\
\hline
\end{tabular}

Concentration of ions in $0.7-\mathrm{g} \mathrm{L}^{-1}$ seawater is shown for comparison. Molar ratios of $\mathrm{Na}^{+}: \mathrm{K}^{+}, \mathrm{Na}^{+}: \mathrm{Ca}^{+2}, \mathrm{~K}^{+}: \mathrm{Cl}^{-}$and Ca ${ }^{+2}: \mathrm{Mg}^{+2}$ are shown for each water type.

${ }^{*}$ In each row means within year with different superscripts are significantly different $(P<0.05)$.

Table 3 Mean early morning water temperature and dissolved oxygen concentration in treatment ponds during the 2003 and 2004 experiments*

\begin{tabular}{|c|c|c|c|c|c|c|}
\hline & \multicolumn{3}{|l|}{2003} & \multicolumn{3}{|l|}{2004} \\
\hline & $\mathrm{PL}_{15}$ & $\mathrm{PL}_{25}-1$ & $\mathrm{PL}_{25}-2$ & $7 \mathrm{~m}^{-2}$ & $13 m^{-2}$ & $30 \mathrm{~m}^{-2}$ \\
\hline Water temperature $\left({ }^{\circ} \mathrm{C}\right)$ & $27.2^{\mathrm{a}}$ & $27.9^{\mathrm{a}}$ & $26.7^{\mathrm{a}}$ & $26.9^{\mathrm{a}}$ & $27.0^{\mathrm{a}}$ & $27.0^{\mathrm{a}}$ \\
\hline Dissolved oxygen $\left(\mathrm{mgL}^{-1}\right)$ & $4.3^{\mathrm{b}}$ & $4.6^{\mathrm{b}}$ & $5.3^{\mathrm{a}}$ & $4.0^{\mathrm{a}}$ & $4.4^{\mathrm{a}}$ & $3.5^{\mathrm{a}}$ \\
\hline
\end{tabular}

*In each row means within year with different superscripts are significantly different $(P<0.05)$. 
Table 4 Production characteristics including specific growth rate (SGR) and gross feed conversion ratio (FCR) of Litopenaeus vannamei (Boone) in ponds filled with freshwater amended with minerals to $0.7 \mathrm{~g} \mathrm{~L}^{-1}$ salinity in 2003 and $2004^{*}$

\begin{tabular}{|c|c|c|c|c|c|c|}
\hline Treatment & Yield $\left(\mathrm{kg} \mathrm{ha}^{-1}\right)$ & Survival (\%) & $\begin{array}{l}\text { Individual weight } \\
\left(\text { g shrimp }^{-1} \text { ) }\right.\end{array}$ & $\begin{array}{l}\text { Weekly growth } \\
\text { (g week }^{-1} \text { ) }\end{array}$ & SGR ( $\%$ day $\left.^{-1}\right)$ & FCR \\
\hline \multicolumn{7}{|l|}{2003} \\
\hline $\mathrm{PL}_{15}$ & $3449^{a}$ & $47.0^{\mathrm{b}}$ & $19.3^{\mathrm{a}}$ & $1.3^{\mathrm{a}}$ & $2.3^{\mathrm{C}}$ & $3.0^{\mathrm{a}}$ \\
\hline \multicolumn{7}{|l|}{$\mathrm{PL}_{25}$} \\
\hline First cycle & $988^{C}$ & $82.3^{\mathrm{ab}}$ & $5.5^{\mathrm{c}}$ & $0.9^{\mathrm{b}}$ & $3.1^{\mathrm{b}}$ & $1.9^{b}$ \\
\hline Second cycle & $2462^{\mathrm{b}}$ & $99.2^{\mathrm{a}}$ & $9.0^{\mathrm{b}}$ & $1.3^{\mathrm{a}}$ & $4.7^{\mathrm{a}}$ & $1.2^{\mathrm{b}}$ \\
\hline \multicolumn{7}{|l|}{2004} \\
\hline $7 \mathrm{PL}_{15} \mathrm{~m}^{-2}$ & 1379 & 94.4 & 20.5 & 1.2 & 2.6 & 1.9 \\
\hline $13 \mathrm{PL}_{15} \mathrm{~m}^{-2} \dagger$ & 2674 & 136.2 & 14.4 & 0.8 & 2.5 & 1.6 \\
\hline $30 \mathrm{PL}_{15} \mathrm{~m}^{-2}$ & 4966 & 94.1 & 17.1 & 1.0 & 2.5 & 1.8 \\
\hline
\end{tabular}

In 2003, $\mathrm{PL}_{15}$ shrimp were stocked at $39 \mathrm{PLm}^{-2}$ for 112 days. $\mathrm{PL}_{25}$ shrimp were stocked at $23 \mathrm{PL} \mathrm{m}^{-2}$ for 55 days (first cycle) followed by $28 \mathrm{PL} \mathrm{m}^{-2}$ for 65 days (second cycle). In 2004, the grow-out period lasted 134 days.

*In each column, means within year with different superscripts are significantly different $(P<0.05)$.

$\dagger$ One replicate pond lost to aerator failure; data excluded.

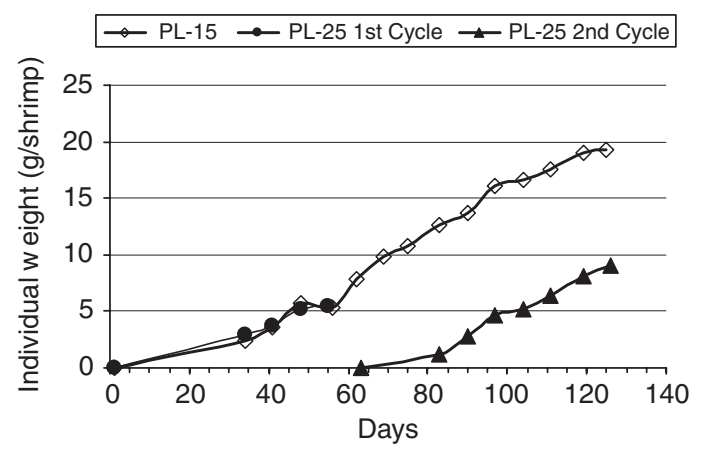

Water temperature increased during May and June, remained relatively constant during July and August, and declined during September. Mean early morning water temperatures and dissolved oxygen concentrations are shown by treatment for each year in Table 3.

Gross yield of heads-on shrimp in 2003 was significantly greater in ponds stocked with $\mathrm{PL}_{15}$ shrimp than in ponds stocked with $\mathrm{PL}_{25}$ shrimp (Table 4). However, the sum of gross yield for the first- and second-production cycles where $\mathrm{PL}_{25}$ shrimp were stocked, i.e., the entire growing season, did not differ significantly from the gross yield for $\mathrm{PL}_{15}$ shrimp. Shrimp growth in the $\mathrm{PL}_{25}$ first-cycle treatment did not appear to differ from that in the $\mathrm{PL}_{15}$ treatment (Fig. 1).

Two separate aerator failures during the $2004 \mathrm{ex}-$ periment resulted in shrimp mass-mortality by hypoxia. The first event occurred on 10 August 2004 (day 94) and the second event on 15 September 2004 (day 130); production data from these ponds were excluded from analyses. Mean production data by treatment are presented in Table 4. Gross yield of heads-on shrimp increased linearly with increased stocking rate $\left(R^{2}=0.989\right.$; Table 4). Shrimp growth in the 13 and $30 \mathrm{PL} \mathrm{m}^{-2}$ treatments appeared to be similar and lower than in the $7 \mathrm{PL} \mathrm{m}^{-2}$ treatment (Fig. 1). tays or $\mathrm{PL}_{25}$ shrimp for 55 days (PL 125 da harvested, and restocked for 65 days ( $\left.\mathrm{PL}_{25} \mathrm{~b}\right)$. In 2004, ponds were stocked with $\mathrm{PL}_{15}$ shrimp for 134 days.

Mean concentrations of minor elements measured in the day 125 samples in 2003 were: aluminum $-0.051 \mathrm{mg} \mathrm{L}^{-1}$, cobalt $-0.000 \mathrm{mg} \mathrm{L}^{-1}$, copper - $0.128 \mathrm{mg} \mathrm{L}^{-1}$, iron $-0.041 \mathrm{mg} \mathrm{L}^{-1}$, manganese $-0.363 \mathrm{mg} \mathrm{L}^{-1}$, molybdenum $-0.008 \mathrm{mg} \mathrm{L}^{-1}$, and zinc $-0.052 \mathrm{mg} \mathrm{L}^{-1}$.

\section{Discussion}

Litopenaeus vannamei survived and grew successfully during two consecutive seasons in inland ponds filled with a hard freshwater amended with sodium, chloride, potassium, magnesium and sulphate to a final mean salinity of $0.7 \mathrm{~g} \mathrm{~L}^{-1}$ in the current study. 
These results contrast with Laramore, Laramore and Scarpa (2001) who found in a 40-day experiment that $\mathrm{PL}_{25}$ and $\mathrm{PL}_{40}$ L. vannamei did not survive at salinity $<2 \mathrm{~g} \mathrm{~L}^{-1}$ and had reduced survival and growth at salinity $<4 \mathrm{~g} \mathrm{~L}^{-1}$. Shrimp survival was significantly lower in water whose source of salinity $\left(2-5 \mathrm{~g} \mathrm{~L}^{-1}\right)$ was mixed salts (chlorides of calcium, magnesium, potassium and sodium) compared with sea salt (artificial seawater salt) (Atwood et al. 2003; Sowers, Gatlin, Young, Isely, Browdy \& Tomasso 2005). However, inclusion of $1 \mathrm{~g} \mathrm{~L}^{-1}$ salinity from sea salt along with salinity derived from mixed salts improved L. vannamei growth and survival (Atwood et al. 2003; Sowers, Tomasso Jr, Browdy \& Atwood 2006). Thus, these authors concluded that sea salt is required for growth and survival of L. vannamei.

Low-salinity ground water is used to culture L. vannamei at inland sites in a number of states in the southern United States. Brackish ground water also has been evaluated for inland culture of marine fish such as red drum (Forsberg et al. 1996) or Australian snapper (Fielder et al. 2001). The ionic proportions found in brackish ground water often differ from those in seawater at the same salinity (Forsberg et al. 1996; Fielder et al. 2001; Boyd \& Thunjai 2003; Partridge \& Creeper 2004). Potassium, magnesium, chloride, and sulphate concentrations in low-salinity ground water can to be lower than those in dilute seawater of the salinity (Boyd \& Thunjai 2003; Zhu et al. 2004). Inland shrimp farmers in the United States have reported shrimp mortality in low-salinity water whose ionic proportions differed from those in seawater (McNevin et al. 2004). Supplementation of ion-deficient saline groundwater with $\mathrm{Mg}^{2+}$ and/or $\mathrm{K}^{+}$significantly improved L. vannamei $\mathrm{PL}_{17}$ survival compared with untreated water (Davis, Boyd, Rouse \& Saoud 2005). Similarly, red drum survival was increased significantly by increasing concentration of deficient ions by mixed salt addition (Forsberg et al. 1996).

Application of potassium magnesium sulphate increased pond $\mathrm{K}^{+}, \mathrm{Mg}^{2+}$ and $\mathrm{SO}_{4}^{2-}$ concentrations, but the post-application $\mathrm{K}^{+}$concentration was only $56-64 \%$ of the target concentration. In a small research pond trial, McNevin et al. (2004) noted that the increase in ionic concentrations only was about $66 \%$ of the expected increases if the applied potassium magnesium sulphate dissolved completely. Pond soils in inland shrimp ponds adsorbed 55\% of added potassium (Boyd, Boyd \& Rouse 2007a). Adsorbed potassium was comprised of exchangeable $\mathrm{K}^{+}$and fixed $\mathrm{K}^{+}$(Boyd et al. 2007a; Boyd, Boyd
\& Rouse 2007b). Soil adsorption of $\mathrm{K}^{+}$likely was responsible for the difference in observed and expected pond water $\mathrm{K}^{+}$concentration in the present experiment.

In evaluating the initial quality and impact of ion amendment to correct deficiencies in low-salinity water, researchers have examined relationships between ratios of metabolically important ions and growth and survival. Red drum survival was positively correlated to $\mathrm{Na}^{+}: \mathrm{K}^{+}$molar ratio and negatively correlated to $\mathrm{K}^{+}: \mathrm{Cl}^{-}$molar ratio in test water at $15 \mathrm{~g} \mathrm{~L}^{-1}$ salinity (Forsberg et al. 1996). However, the authors attributed these correlations to high within-treatment variation. Fielder et al. (2001) evaluated short-term growth and survival of Australian snapper in brackish ground water $\left(19.6 \mathrm{~g} \mathrm{~L}^{-1}\right.$ salinity) amended with potassium chloride $\left(\mathrm{K}^{+}: \mathrm{Cl}^{-}\right.$molar ratio varied from 0.001-0.018). Fish died at a $\mathrm{K}^{+}: \mathrm{Cl}^{-}$ratio less than 0.007 and maximum growth occurred above a ratio of 0.010. Juvenile barramundi (Lates calcarifer [Bloch]) died during a bioassay in saline groundwater whose $\mathrm{K}^{+}: \mathrm{Cl}^{-}$molar ratio was 0.005 (Partridge \& Creeper 2004). The principal cause of barramundi death, as determined by postmortem examination, was skeletal myopathy caused by potassium-deficient groundwater.

Seven-d shrimp survival was not correlated with $\mathrm{Na}^{+}: \mathrm{K}^{+}, \mathrm{Ca}^{2+}: \mathrm{Mg}^{2+}$, or $\mathrm{Na}^{+}: \mathrm{Ca}^{2+}$ molar ratios in environments where salinity $\left(1-5 \mathrm{gL}^{-1}\right)$ was derived from sea salt and mixed salts dissolved in soft water (Atwood et al. 2003). However, there was a positive correlation between survival and $\mathrm{K}^{+}: \mathrm{Cl}^{-}$molar ratio over the range of 0.008-0.018. Shrimp survival at 21 days was not correlated to any ion ratio. In another study at $30 \mathrm{~g} \mathrm{~L}^{-1}$ salinity, no L. vannamei survived at a $\mathrm{Na}^{+}: \mathrm{K}^{+}$molar ratio of 187.4 , and the growth and energy budget of shrimp in water with a $\mathrm{Na}^{+}: \mathrm{K}^{+}$ratio of 153.3 was significantly lower than for shrimp at lower ratios (Zhu et al. 2004).

In the present experiment, the $\mathrm{Na}^{+}: \mathrm{K}^{+}$and $\mathrm{Na}^{+}: \mathrm{Ca}^{2+}$ molar ratios were lower than those in seawater at the same salinity because concentrations of potassium and calcium were relatively higher and concentration of chloride was relatively lower. Molar ratios of $\mathrm{K}^{+}: \mathrm{Cl}^{-}$and $\mathrm{Ca}^{2+}: \mathrm{Mg}^{2+}$ were higher than those in seawater at the same salinity because concentration of chloride was relatively lower, and concentrations of calcium and magnesium were relatively higher. The excess or deficient concentration compared with dilute seawater at the same salinity of calcium $(555 \%)$, magnesium $(146 \%)$, potassium (334\%), sulphate $(130 \%)$, chloride $(65 \%)$ or sodium 
(93\%) did not appear to impact negatively shrimp survival and growth. Clearly, L. vannamei grew well in an ionic environment that differed from that of dilute seawater. Perhaps achieving a minimum concentration of major ions is important to ensuring survival in ion-deficient waters. McGraw and Scarpa (2003) suggested that a minimum $\mathrm{K}^{+}$concentration of $1 \mathrm{mg} \mathrm{L}^{-1}$ in a $1 \mathrm{~g} \mathrm{~L}^{-1}$ salinity water was required for L. vannamei survival. However, shrimp survival was monitored only for $48 \mathrm{~h}$. It is unlikely shrimp would survive for an extended period in this water because the $\mathrm{K}^{+}: \mathrm{Cl}^{-}$molar ratio was 0.0014 . What remains is to determine the minimum concentrations of major ions for good survival and growth of L. vannamei.

Shrimp yields ranged from $3449 \mathrm{~kg} \mathrm{ha}^{-1}$ in 2003 to $4966 \mathrm{~kg} \mathrm{ha}^{-1}$ in 2004 in ponds stocked with 30-39 $\mathrm{PL}_{15} \mathrm{~m}^{-2}$ for a 125-134-d culture period. At harvest, mean individual weight ranged from 17.1-19.3 g shrimp $^{-1}$, which were considered marketable size shrimp. Similar results have been reported for L. vannamei in studies in coastal ponds. During a 112-day experiment where $\mathrm{PL}_{10}$ L. vannamei was stocked at $35 \mathrm{PLm}^{-2}$, mean yield was $3525 \mathrm{~kg} \mathrm{ha}^{-1}$ and mean weight was $15.0 \mathrm{~g} \mathrm{shrimp}^{-1}$ (Garza de Yta, Rouse \& Davis 2004). The difference in mean weight between the two experiments likely resulted from a lower survival and higher growth rate in the present experiment. In another 112-day study stocked at $35 \mathrm{PL} \mathrm{m}^{-2}$, age of L. vannamei at stocking did not affect significantly mean gross yield (3375$4005 \mathrm{~kg} \mathrm{ha}^{-1}$ ) or mean individual weight at harvest (15.0-16.9 g shrimp $^{-1}$ ) (Zelaya, Rouse \& Davis 2007). After a 4-month growing season in ponds on an inland farm stocked with $40 \mathrm{PL} \mathrm{m}^{-2}$, L. vannamei yield averaged $4500 \mathrm{~kg} \mathrm{ha}^{-1}$ and mean individual weight ranged from 17.5-21.0 $\mathrm{g} \mathrm{shrimp}^{-1}$ (Samocha et al. 2002). Mean L. vannamei yield after 203 days ranged from $2920-3325 \mathrm{kgha}^{-1}$ in ponds stocked with $15 \mathrm{PL} \mathrm{m}^{-2}$ on a farm in Sonora, Mexico (CasillasHernández, Magallón-Barajas, Portillo-Clarck \& Páez-Osuna 2006). However, because of the longer grow out period mean final weight (29.532.3 g shrimp $^{-1}$ ) exceeded that obtained in the present study.

While total shrimp yield for the growing season was similar for the $\mathrm{PL}_{15}$ and $\mathrm{PL}_{25}$ treatments, producing two crops of marketable shrimp during the early May to early October growing season by stocking PL25 shrimp appears doubtful because of the low mean weight at harvest. If ponds had been stocked in early May as opposed to late May, mean final weights would have been greater in both the $\mathrm{PL}_{15}$ and $\mathrm{PL}_{25}$-first cycle treatments. However, it is unlikely the shrimp harvested from the $\mathrm{PL}_{25}$-first cycle treatment would have been larger than those harvested from the $\mathrm{PL}_{25}$-second cycle treatment.

In summary, this is the first published report that freshwater can be amended with key ions to permit production of L. vannamei in inland ponds. Salinity of source freshwater was increased to $0.7 \mathrm{~g} \mathrm{~L}^{-1}$. Thus, the presence of brackish ground water does not appear to be a necessary prerequisite for inland culture of L. vannamei. However, the ionic composition of source water will determine the quantities of minerals necessary to amend ion concentrations to desired levels. Additional research is needed to determine the minimum concentrations of major anions and cations for L. vannamei.

\section{Acknowledgments}

The ARS and UAPB Aquaculture Research Station support personnel and UAPB students are thanked for their assistance during these studies, especially at harvests. Mention of trade names or commercial products is solely for the purpose of providing specific information and does not imply recommendation or endorsement by the U.S. Department of Agriculture.

\section{References}

Atwood H.T., Young S.P., Tomasso J.R. \& Browdy C.L. (2003) Survival and growth of Pacific white shrimp Litopenaeus vannamei postlarvae in low-salinity and mixed-salt environments. Journal of the World Aquaculture Society 34, 518 523.

Bohn H.L., McNeal B.L. \& O'Connor G.A. (1985) Soil Chemistry, Second Edition. John Wiley and Sons, New York, USA.

Boyd C.E. \& Thunjai T. (2003) Concentrations of major ions in waters of inland shrimp farms in China, Ecuador,Thailand, and the United States. Journal of the World Aquaculture Society 34, 524-532.

Boyd C.A., Boyd C.E. \& Rouse D.B. (2007a) Potassium budget for inland, saline water shrimp ponds in Alabama. Aquacultural Engineering 36, 45-50.

Boyd C.A., Boyd C.E. \& Rouse D.B. (2007b) Potassium adsorption by bottom soils in ponds for inland culture of marine shrimp in Alabama. Journal of the World Aquaculture Society 37, 85-91.

Casillas-Hernández R., Magallón-Barajas F., Portillo-Clarck G. \& Páez-Osuna F. (2006) Nutrient mass balances in semi-intensive shrimp ponds from Sonora, Mexico using 
two feeding strategies: trays and mechanical dispersal. Aquaculture 258, 289-298.

Clifford H.C. III (1992) Marine shrimp pond management: a review. In: Proceeding of the Special Session on Shrimp Farming (ed. by J.Wyban), pp. 110-137. World Aquaculture Society, Baton Rouge, LA, USA.

Davis D.A., Boyd C.E., Rouse D.B. \& Saoud I.P. (2005) Effects of potassium, magnesium and age on growth and survival of Litopenaeus vannamei post-larvae reared in inland low salinity well waters in west Alabama. Journal of the World Aquaculture Society 36, 416-419.

Fielder D.S., Bardsley W.J. \& Allan G.L. (2001) Survival and growth of Australian snapper, Pagrus auratus, in saline groundwater from inland New South Wales, Australia. Aquaculture 201, 73-90.

Forsberg J.A., Dorsett P.W. \& Neill W.H. (1996) Survival and growth of red drum Sciaenops ocellatus in saline groundwaters of west Texas, USA. Journal of the World Aquaculture Society 27, 462-474.

Garza deYta A., Rouse D.B. \& Davis D.A. (2004) Influence of nursery period on the growth and survival of Litopenaeus vannamei under pond production conditions. Journal of the World Aquaculture Society 35, 357-365.

Laramore S., Laramore C.R. \& Scarpa J. (2001) Effect of low salinity on growth and survival of postlarvae and juvenile Litopenaeus vannamei. Journal of the World Aquaculture Society 32, 385-392.

McGraw W.J. \& Scarpa J. (2003) Minimum environmental potassium for survival of Pacific white shrimp Litopenaeus vannamei (Boone) in Freshwater. Journal of Shellfish Research 22, 263-267.

McNevin A.A., Boyd C.E., Silapajarn O. \& Silaparjarn K. (2004) Ionic supplementation of pond waters for inland culture of marine shrimp. Journal of the World Aquaculture Society 35, 460-467.

Partridge G.J. \& Creeper J. (2004) Skeletal myopathy in juvenile barramundi, Lates calcarifer (Bloch), cultured in potassium-deficient saline groundwater. Journal of Fish Diseases 27, 523-530.

SamochaT.M., Hamper L., Emberson C.R., Davis A.D., McIntosh D., Lawrence A.L. \& Van Wyk P.M. (2002) Review of some recent developments in sustainable shrimp farming practices in Texas, Arizona, and Florida. Journal of Applied Aquaculture 12, 1-42.

Saoud I.P., Davis D.A. \& Rouse D.B. (2003) Suitability studies of inland well waters for Litopenaeus vannamei culture. Aquaculture 217, 373-383.

Sokal R.R. \& Rohlf F.J. (1995) Biometry: The Principles and Practice of Statistics in Biological Research, Third Edition. W. H. Freeman and Company, New York, USA.

Sowers A.D., Gatlin D.M., Young S.P., Isely J.J., Browdy C.L. \& Tomasso J.R. (2005) Responses of Litopenaeus vannamei (Boone) in water containing low concentrations of total dissolved solids. Aquaculture Research 36, 819-823.

Sowers A.D., Tomasso J.R. Jr., Browdy C.L. \& Atwood H.L. (2006) Production characteristics of Litopenaeus vannamei in low-salinity water augmented with mixed salts. Journal of the World Aquaculture Society 37, 214-217.

Zelaya O., Rouse D.B. \& Davis D.A. (2007) Growout of Pacific white shrimp, Litopenaeus vannamei, stocked into production ponds at three different ages. Journal of the World Aquaculture Society 38, 92-101.

Zhu C., Dong S., Wang F. \& Huang G. (2004) Effects of Na/K ratio in seawater on growth and energy budget of juvenile Litopenaeus vannamei. Aquaculture 234, 485-496. 